\title{
23andMe sets sights on UK/Canada, signs up Genentech
}

Late in 2014, 23andMe launched its directto-consumer personal genetics service in Canada and the UK. For the Mountain View, California-based company, the move into smaller markets marks a new horizon for the company since suspending its US healthrelated genetic testing almost a year ago following a warning letter from regulators (Nat. Biotechnol. 32, 1, 2014). Also, last month, 23andMe partnered with Genentech of S. San Francisco, California, to provide whole genome sequence data to fuel discovery of Parkinson's disease drugs, a further sign that the personal genetics company remains committed to exploring new routes to revenue.

British medical geneticists were skeptical about the likely uptake of the $£ 125$ (\$189) spit test in the UK. "I don't have a sense that there is a great appetite for direct-to-consumer patient testing in the UK," says Bill Newman, professor of translational genomic medicine at The University of Manchester, and chairelect for the British Society for Genetic Medicine. He pointed to previous products from genomics testing companies that have failed to succeed in the UK, including one test that was briefly sold by cosmetics store The Body Shop, acquired in 2006 by L'Oreal.

Anneke Lucassen, professor of clinical genetics at the University of Southampton and member of the Nuffield Council on Bioethics, agrees. "There is a slightly different mentality here than there is in the States," she notes, adding that people tend to be less willing to pay for private healthcare tests because the National Health Service covers the costs of necessary medical tests.

Canada, too, has a universal healthcare system and just over half the population base of the UK.

23andMe has not disclosed its market expectations for the UK and Canada. But before the company launched in the UK, 10,000 British consumers had signed up for 23andMe's services, paying an additional shipping fee from the US. 23 andMe has a total of 800,000 customers.

23 and Me is continuing to work with the FDA to get its tests approved in the US, says a company spokesperson, adding that a $510(\mathrm{~K})$ application for a Bloom Syndrome report currently under review by the agency "could provide a foundation for future submissions." Newman and Lucassen speculated that one motive for the new launches could be to smooth discussions with the FDA. "My feeling is that coming into Europe is just the

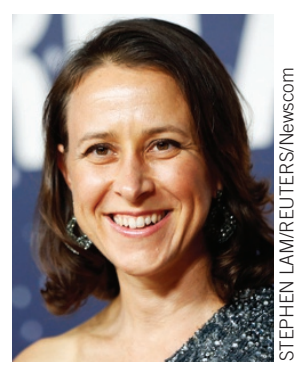

23andMe's co-founder Wojcicki and CEO Anne

company's way of trying to get in through the back door. They might then be able to say, look, we launched it successfully in Europe, and use that as a means to appeal to the FDA to relaunch it in the states," says Lucassen.

In the UK, the company will sell DNA kits and reports on 43 inherited conditions (including cystic fibrosis and sickle cell anemia), 12 drug responses (including Plavix (clopidogrel) and Coumadin (warfarin)), 11 genetic risk factors (including Alzheimer's and Parkinson's) and 40 traits (including alcohol flush reaction and ear wax type). The test will also provide genetic ancestry data and enable UK customers to participate in 23andMe's genetic research program. In Canada, the spit test covers two additional inherited conditions and two additional traits. "Information from certain reports could be incorporated into the management of an individual's healthcare upon consultation with a doctor," says a company spokesperson. "Other results are simply interesting and informative."

For Newman, however, the clinical utility of many of 23andMe's genetic analyses remains debatable. With the additional caveat that, if genetic information isn't conveyed or interpreted properly, customers may be falsely reassured or unnecessarily stressed by the results. "I can't quite see the benefit of this type of testing for myself or for many people," he says, "but that's not to say that people shouldn't have the choice to have that testing."

The deal struck with Genentech is not based on selling DNA tests but on data collected from its consumer base. According to Forbes, Genentech paid \$10 million upfront and committed $\$ 50$ million in milestones. Under the terms of the collaboration, 23andMe will carry out whole genome sequencing in approximately 3,000 people with Parkinson's disease to generate therapeutic target leads. In the past, 23andMe has struck similar deals with other drug developers, including a deal last year with Pfizer of New York to study the genetic factors associated with inflammatory bowel disease. (Nat. Biotechnol. 32, 967, 2014)

Asher Mullard Ottawa, Canada

\section{Ebola+ and IMI 2}

On January 16, the first eight Ebola+ projects, funded by the EU's Innovative Medicines Initiative, got underway. The Ebola+ scheme launched in November 2014 in response to the ongoing outbreak in western Africa aims to accelerate vaccine development, manufacture, uptake and diagnostics. The total budget of $€ 215$ (\$250) million stems from a consortia of over 40 partners in pharma, diagnostics, academia, public health organizations and small biotechs. Also, the IMI 2 released its third and fourth calls for proposals. The focus is on projects relating to whooping cough (pertussis) vaccination research, risk and progression of prediabetes and type 2 diabetes, neuropsychiatry, the remote assessment of disease and establishing a platform to speed up patient access to new therapies. The program's total $€ 115$ (\$133.7) million will come from the European Commission's Horizon 2020 program for research and innovation, the European Federation of Pharmaceutical Industries and Associations, and other industry partners. The Bill and Melinda Gates Foundation will collaborate with IMI 2 on the pertussis project. The third call has a March 24 deadline and the fourth call a February 11 deadline.

\section{UK catapults precision medicine}

As part of the government's $£ 5.9$ (\$9.3)-billion science and innovation strategy for 2015-2021, the UK is launching a 'Precision Medicine Catapult' in 2015. The state-funded plan pledges to create a National Formulation Centre to support emerging local companies to produce medicines and chemicals that are deemed high risk or technically challenging. The UK already has seven catapults, including one dedicated to cell therapies (Nat. Biotechnol. 32, 736-741, 2014).

\section{Moderna's \$450-million venture round}

Four-year old Moderna Therapeutics raised a whopping $\$ 450$ million in a financing round in December, shattering all previous records for a privately held biotech company. The earlystage firm, whose therapeutic platform relies on transforming cells with synthetic mRNA constructs, has raised nearly $\$ 1$ billion to date. The latest financing round for Moderna is remarkable in that the Cambridge, Massachusetts, company has not a single candidate in clinical development, and few details of the technology have been disclosed (Nat. Biotechnol. 31, 476-478, 2013).

\section{C "People think that whole genome sequencing must be the gold standard of looking at DNA, but it really doesn't} detect all types of genetic structures." Mildred Cho of Stanford University, commenting on a study published in Genetics in Medicine in December showing that $83 \%$ of parents favor sequencing their newborn's DNA when asked within 48 hours after a birth.

(San Francisco Gate, 2 January 2015) 